\title{
PENGARUH KOMPETENSI TENAGA KEPENDIDIKAN TERHADAP KINERJA TENAGA KEPENDIDIKAN DI SMK NEGERI 4 KENDARI
}

\author{
Askam Rio $^{\varpi_{1}}$, Muh. Alamsah ${ }^{2}$, Apriani Safitri $^{3}$ \\ Program Studi Administrasi Pendidikan, Universitas Muhammadiyah \\ Kendari123 \\ Email: askamrio13@gmail.com
}

\begin{abstract}
ABSTRAK
Tujuan dalam penelitian ini adalah untuk mengetahui pengaruh kompetensi tenaga kependidikan terhadap kinerja tenaga kependidikan di SMK Negeri 4 Kendari. Jenis penelitian ini adalah penelitian kuntitatif. Populasi adalah kepala sekolah dan seluruh tenaga kependidikan yang berjumlah 84 orang, sampel yang digunakan dalam penelitian ini adalah sebanyak jumlah populasi yaitu 84 orang, sehingga disebut dengan penelitian populasi. Teknik pengumpulan data yang digunakan dalam penelitian ini berupa observasi, angket, dan dokumentasi. Teknik analisis data yang digunakan dalam penelitian ini adalah statistik deskriptif dan statistik inferensial. Berdasarkan hasil penelitian dan pembahasan, menunjukan bahwa: (1) Ada pengaruh positif dan signifikan antara kompetensi tenaga kependidikan terhadap kinerja tenaga kependidikan di SMK Negeri 4 Kendari yaitu sebesar 45,02\% dengan nilai koefisien korelasi sebesar 0,671 dan persamaan regresi linear sederhana dengan nilai $\hat{Y}=85,448+4,074 \mathrm{X}$ sedangkan selebihnya yaitu $54,98 \%$ dipengaruhi oleh faktor lain yang tidak diteliti dalam penelitian ini.
\end{abstract}

Kata Kunci: kompetensi tenaga kependidikan, kinerja tenaga kependidikan

\begin{abstract}
The formulation of the problem in this research is: What is the effect of competence of teaching staff energy performance of teaching staff at SMK Negeri 4 Kendari? The aim in this study was to determine : the effect of competence of educational personnel in on the performance of educators in SMK Negeri 4 Kendari. This type of research is a quantitative research. The population is the principal and all education staff, amounting to 84 people, the sample used in this study is the total population, namely 84 people, so it is called a population study. Data collection techniques used in this study were observation, questionnaires, and documentation. The data analysis technique used in this research is descriptive statistics and inferential statistics. Based on the results of research and discussion, it shows that: There is a positive and significant influence between the competence of educational personnel on the performance of educational personnel in SMK Negeri 4 Kendari, namely $45.02 \%$ with a correlation coefficient value of 0.671 and a simple linear regression equation with a value of $\hat{Y}$ $=85.448+4.074 \mathrm{X}$ while the rest is $54,98 \%$ are influenced by other factors not examined in this study.
\end{abstract}

Keywords: competence of Education personnel, performance of education Personnel 


\section{PENDAHULUAN}

Pendidikan juga bertujuan sebagai sarana pembinaan serta pengembangan kerjasama antar individu dengan kelompok atau anggota organisasi. Dengan ini diharapkan dapat mewujudkan pembinaan pendidikan antar individu agar mempunyai rasa saling menghargai dan dihargai sehingga mampu mengaplikasikan praktik tersebut dalam skala besar sebagai bekal untuk berdampingan dengan individu lain dalam bentuk warga negara. Dalam upaya meningkatkan kualitas pendidikan yang berkaitan dengan aspek-aspek dalam proses pendidikan salah satunya adalah meningkatkan kinerja tenaga kependidikan di suatu lembaga sekolah. Keberadaan tenaga kependidikan sangatlah penting untuk menunjang kualitas pendidikan formal serta kegiatan sekolah untuk mencapai tujuan sekolah. Dalam upaya untuk menunjang kualitas pendidikan yang berkaitan dengan proses pendidikan salah satunya adalah dengan meningkatkan kompetensi tenaga kependidikan.

Kompetensi menunjukkan keterampilan atau pengetahuan yang dicirikan oleh profesionalisme dalam suatu bidang tertentu sebagai suatu bagian terpenting, sebagai unggulan bidang tersebut. Kompetensi merupakan karakteristik individu yang mendasari kinerja atau perilaku ditempat kerja. Kinerja dipekerjaan dipengaruhi oleh; pengetahuan, kemampuan, dan sikap; gaya kerja, kepribadian, kepentingan/minat, dasar-dasar, nilai sikap, kepercayaan, dan gaya kepemimpinan, (Wibowo, 2010: 324-325).

Amin Widjaja (2013: 429), mendefinisikan kompetensi yakni kompetensi adalah pengetahuan dan keahlian yang diperlukan untuk mencapai tugas yang menentukan pekerjaan individual. Sementara Mulyadi (2013: 58), mendefinisikan bahwa kompetensi yaitu kompetensi menunjukkan terdapatnya pencapaian dan pemeliharaan suatu tingkatan pemahaman dan pengetahuan yang memungkinkan seorang anggota untuk memberikan jasa dengan kemudahan dan kecerdikan.

Kompetensi yang dimiliki tenaga kependidikan menunjukan keprofesinalannya dalam melakukan tugas dan fungsinya yang ditunjukan melalui kinerjanya. Wujud keprofesionalan tenaga kependidikan adalah memiliki kompetensi dalam hal manajemen sekolah seperti yang diuraikan dalam Permendiknas No. 24 Tahun 2008 tentang standar tenaga kependidikan. Kompetensi tersebut meliputi kompetensi manajerial, kompetensi sosial, kompetensi teknis, dan kompetensi kepribadian. Sebagai seorang tenaga kependidikan sekolah yang profesional dituntut untuk mampu menjalankan tugas dengan baik dan bertanggung jawab sesuai dengan tugas pokok dan fungsinya. Mengingat tenaga kependidikan merupakan tenaga yang harus mempunyai keterampilan dan keprofesionalan dalam bidang kependidikan, agar penyelenggaraan pendidikan berjalan dengan rapi sesuai dengan struktur yang sesuai dengan kelebihan masing-masing personal, selain untuk mengatur sistem secara rinci dan rapi, tenaga administrasi sekolah juga sangat berperan penting dalam mengembangkan lembaga sekolah dan diutamakan selain tenaga pendidik atau guru.

Spencer and Spencer (Ardi dan Dedik, 2019), menyatakan indikator pengukuran kompetensi terdiri dari sebagai berikut: 1) pengetahuan, pengetahuan merujuk pada informasi dan hasil pembelajaran, seperti pengetahuan seorang ahli bedah tentang anatomi manusia. 2) keterampilan, keahlian merujuk pada 
kemampuan seseorang untuk melakukan suatu kegiatan, seperti keahlian bedah untuk melakukan operasi. 3) sikap, perilaku responden didalam merespon sesuatu dalam melaksanakan pekerjaan. Variabel ini diamati dari 5 dimensi yaitu, reaksi, tindakan, memihak, evaluasi, perasaan terhadap pelaksanaan pekerjaan

Peran tenaga kependidikan di lembaga sekolah yaitu melayani pekerjaanpekerjaan operatif untuk mencapai tujuan dari suatu organisasi, menyediakan ketererangan-keterangan bagi pimpinan, dan membantu kelancaran perkembangan organisasi secara keseluruhan. Oleh karena itu, dalam sebuah lembaga sekolah dibutuhkan tenaga tata usaha yang memiliki kompetensi dalam bidangnya. Jika tenaga tata usaha tidak memiliki kompetensi maka tujuan dari sekolah tersebut tidak tercapai.

Kata kependidikan berkenaan dengan bidang pekerjaan mendidik. Kata ini berasal dari kata pendidik mendapat awalan "ke" dan berakhiran "an", berarti proses atau kegiatan mendidik. Dalam konteks pendidikan di Indonesia, kata pendidikan berarti sama dengan menunjuk kata "keguruan dan ilmu pendidikan" sehingga apabila dikaitkan dengan tenaga kependidikan berarti orang-orang yang terlibat dalam proses kegiatan pendidikan (Yahya, 2018). Undang-Undang Sistem Pendidikan Nasional No. 20 Tahun 2003 khususnya Bab I Pasal 1 ayat (5) menyebutkan bahwa tenaga kependidikan adalah anggota masyarakat yang mengabdikan diri dan diangkat untuk menunjang penyelenggaraan pendidikan. Dimana tenaga kependidikan tersebut memenuhi syarat yang ditentukan oleh undang-uandang yang berlaku, diangkat oleh pejabat yang berwenang, diserahi tugas dalam suatu jabatan dan digaji pula menurut aturan yang berlaku.

Kompetensi yang dimiliki tenaga kependidikan akan mempengaruhi kinerjanya. August W. Smith, (Rusman, 2011: 318), kinerja adalah hasil sesuatu proses yang dilakukan manusia. Dengan demikian dapa disimpulkan bahwa kinerja adalah suatu wujud perilaku seseorang yang berorientasi pada prestasi. Sedangkan menurut Moeheriono (2012: 95), kinerja atau performance merupakan gambaran tingkat pencapaian pelaksanaan suatu program kegiatan atau kebijakan dalam mewujudkan sasaran, tujuan, visi dan misi organisasi yang dituangkan dalam perencanaan strategis organisasi.

Indikator kinerja adalah suatu variabel yang digunakan untuk menekspresikan secara kuantitatif efektifitas dan efisiensi proses atau operasi dengan berpedoman pada target-target dan tujuan organisasi. Untuk menentukan kinerja seorang tenaga kependidikan, maka yang perlu diperhatikan adalah pencapaian tenaga kependidikan tersebut dalam melaksanakan tugas dan tanggung jawabnya, Lohman (Abdullah, 2014: 145). Indikator untuk menilai kinerja tenaga kependidikan dalam hal pelayanan dapat dilihat dari beberapa hal yaitu : 1) tanggung jawab, 2) kualitas, 3) kuantitas, dan 4) disiplin.

Beberapa penelitian yang relevan dengan penelitian ini yakni penelitian yang dilakukan oleh Wulan Sari (2014) dalam penelitiannya tentang pembinaan profesionalitas tenaga administrasi sekolah/madrasah di SD/MI se-Kecamatan Pleret Kabupaten Bantul. Hasil penelitian menunjukkan bahwa: (1) Tenaga kependidikan di SD/MI Se-Kecamatan Pleret cukup profesional, indikatornya adalah dari tujuh komponen kegiatan administrasi sekolah/madrasah yang sudah dilaksanakan oleh tenaga kependidikan. Namun, pada bagian pengelolaan arsip beberapa cenderung bekerja tanpa tuntutan/arahan dari kepala sekolah sehingga bekerja berdasarkan 
keyakinannya sendiri dan tidak sesuai dengan prosedur kearsipan yang seharusnya dan; (2) Upaya yang dilakukan untuk meningkatkan profesionalitasnya adalah belajar secara mandiri dibantu dengan kepala sekolah/madrasah dan kepala sekolah mengikutkan pada diklat dan sosialisasi serta pembinaan dari kepala sekolah dan; (3) Faktor-faktor yang berperan terhadap peningkatan profesionalitas tenaga kependidikan di SD/MI Se-Kecamatan Pleret yaitu motivasi kerja dan mengembangkan diri, kepemimpinan kepala sekolah/madrasah, ketersediaan sarana prasarana kerja, dan iklim kerja.

Selanjutnya penelitian yang dilakukan oleh Wenny Fitria Azizah (2016) dalam penelitiannya tentang analisis kompetensi tenaga tata usaha untuk meningkatkan kualitas administrasi sekolah Di SMP Negeri 4 Yogyakarta. Hasil penelitian menunjukkan bahwa: 1) Kompetensi yang ada dalam tenaga tata usaha di SMP N 4 Yogyakarta sudah sesuai dengan standar kompetensi tenaga tata usaha yang ada dalam Peraturan Pemerintah Pendidikan Nasional No. 24 tahun 2008 yang berisi tentang kompetensi kepribadian, sosial, tekhnis, dan menejerial. 2) Upaya tenaga tata usaha untuk meningkatkan kualitas administrasi sekolah di SMP Negeri 4 Yogyakarta adalah dengan a) tidak menunda pekerjaan yang sudah diberikan kepada masing-masing bagian, b) memaksimalkan dalam memberikan pelayanan yang baik terhadap guru, karyawan dan peserta didik, c). menjalin hubungan kerjasama dengan pemerintah dan lembaga lembaga masyarakat, d) menjaga dan memelihara barang-barang dan alat-alat inventaris sekolah. e) memanage anggaran atau dana dari pemerintah sesuai dengan skala kebutuhan, f) melakukan studi banding ke sekolah lain yang lebih maju, g). melengkapi sarana prasarana. 3) Faktor pendukung terciptanya kerjasama yang baik antar tenaga kependidikan atau karyawan, saling membantu pekerjaan antar tenaga kependidikan, saling menciptakan suasana kerja yang harmonis antar karyawan, saling menghargai dan memahami karakter masing-masing tenaga kependidikan atau karyawan. Sedangkan faktor penghambatnya yaitu kurangnya sumber daya manusia dalam melaksanakan pekerjaan sesuai bidang masing-masing, dan kurangnya keahlian tenaga kependidikan dalam mengoperasikan komputer.

Berdasarkan hasil observasi awal yang diperoleh oleh peneliti tentang kompetensi tenaga kependidikan sekolah di SMK Negeri 4 Kendari masih ada beberapa yang kurang memahami apa yang harus dilakukan dan dikerjakan oleh seorang tenaga kependidikan di sekolah. Dengan demikian tujuan dalam penelitian ini dalah untuk mengetahui pengaruh kompetensi tenaga kependidikan terhadap kinerja tenaga kependidikandi SMK Negeri 4 Kendari.

\section{METODE PENELITIAN}

Jenis penelitian yang digunakan dalam penelitian tentang pengaruh kompetensi terhadap kinerja tenaga kependidikan di SMK Negeri 4 Kendari menggunakan metode penelitian kuantitatif. Menurut Sugiyono (2015: 23) data kuantitatif adalah data yang berbentuk angka, atau data kuantitatif yang diangkakan (scoring). Jadi data kuantitatif merupakan data yang memiliki kecenderungan dapat dianalisis dengan cara atau teknik statistik. Data tersebut dapat berupa angka atau skor dan biasanya diperoleh dengan menggunakan alat pengumpul data yang jawabannya berupa rentang skor atau pertanyaan yang diberi bobot.

Variabel dalam penelitian ini terdiri dari 1 (satu) variabel bebas (independent), dan 1 (satu) variabel terikat (dependent). Variabel bebas (independent) adalah kompetensi tenaga kependidikan yang selanjutnya dalam penelitian ini diberi notasi $\mathrm{X}$ sedangkan Variabel terikat (dependent) adalah kinerja tenaga kependidikan yang 
selanjutnya dalam penelitian ini diberi notoasi Y. Jumlah keseluruhan populasi dalam penelitian ini adalah 84 orang yang terdiri dari kepala sekolah, 75 orang guru dan 8 orang tenaga administrasi sekolah. Dalam bukunya, Arikunto (2006: 112) mengatakan bahwa "jika jumlah populasi kurang dari 100, akan lebih baik jika diambil secara keseluruhan, dan penelitian ini disebut juga dengan penelitian populasi, jika jumlah populasi lebih dari 100 , dapat diambil $10-15 \%$ atau $20-25 \%$ atau lebih". Jadi sampel dalam penelitian ini adalah sebanyak jumlah populasi yaitu 86 orang, sehingga disebut dengan penelitian populasi.

Penelitian ini menggunakan 1 (satu) variabel terikat yaitu kompetensi tenaga kependidikan dan 1 (satu) variabel bebas yaitu kinerja tenaga kependidikan. Variabel bebas diukur menggunakan instrumen pernyataan dengan mengggunakan skala likert dengan ketentuan: (1) Jawaban sangat setuju (SS) diberikan skor 5; (2) Jawaban setuju (S) diberikan skor 4; (3) Jawaban ragu-ragu (RR) diberikan skor 3; (4) Jawaban tidak setuju (TS) diberikan skor 2; (5) Jawaban sangat tidak setuju (STS) diberikan skor 1 .

Uji Validitas Instrumen dikatakan valid jika instrumen dapat mengukur sesuatu dengan tepat terhadap apa yang hendak diukur. Adapun yang digunakan untuk menguji bisa dengan Uji SPSS atau dengan rumus koefisien korelasi product moment dari Karl Pearson. Uji validitas instrumen dalam penelitian ini penulis menggunakan Uji SPSS. Berikut adalah rumus koefisien korelasi product moment:

$$
r_{\infty}=\frac{\sum x \cdot}{\sqrt{\left(\sum x^{2}\right)\left(\sum v^{2}\right)}}
$$

Dimana;

$\mathrm{r}_{\mathrm{xy}} \quad=$ koefisien korelasi antara variabel $\mathrm{X}$ dan variabel $\mathrm{Y}$

$\Sigma_{\mathrm{xy}} \quad=$ jumlah perkalian $\mathrm{x}$ dengan $\mathrm{y}$

$\mathrm{x}^{2} \quad=$ kuadrat dari $\mathrm{x}$

$\mathrm{y}^{2} \quad=$ Kuadrat dari y. (Arikunto, 2009: 70).

Dengan taraf signifikan 5\% apabila dari hasil penghitungan di dapat $\mathbf{r}_{\text {hitung }}>$ $r_{\text {tabel }}$ maka dikatakan butir instrumen nomor tersebut telah signifikan atau telah valid. Apabila $r_{\text {hitung }}<r_{\text {tabel }}$ maka butir instrumen tersebut tidak signifikan atau tidak valid.

Uji reliabilitas instrumen digunakan untuk menunjukkan bahwa suatu instrumen cukup dapat dipercaya untuk digunakan sebagai alat pengumpul data karena instrumen tersebut sudah baik. Untuk perhitungan reliabilitas dalam penelitian ini digunakan rumus sebagai berikut:

$$
r_{11}=\left|\frac{n}{n-1}\right|\left[1-\frac{\sum \sigma_{i}^{2}}{\sigma_{t}^{2}}\right]
$$

Keterangan :

$\mathrm{r}_{11}=$ reliabilitas instrumen

$\Sigma \sigma_{\mathrm{b}}{ }^{2}=$ jumlah varians butir tiap item

$\mathrm{n}=$ banyaknya item

$\sigma_{\mathrm{t}^{2}}=$ varian total .

Rumus varian:

$$
\sigma^{2}=\frac{-\Sigma x^{2}-\frac{(\Sigma x)^{2}}{N}}{N}
$$

Kemudian hasil $\mathrm{r}_{11}$ yang didapat dari perhitungan dibandingkan dengan harga tabel $r$ product moment. Harga $r_{\text {tabel }}$ dihitung dengan taraf signifikansi $5 \%$ dan kepada 
sesuai dengan butir soal, jika $r_{11}>r_{\text {tabel, }}$ maka dapat dinyatakan butir soal tersebut reliabel.

Untuk memperoleh data yang benar-benar akurat dan sesuai, penelitian ini menggunakan teknik pengumpulan data sebagai berikut: 1) Angket adalah teknik pengumpulan data yang dilakukan dengan cara memberi seperangkat pertanyaan atau pernyataan tertulis kepada responden untuk dijawabnya. Kuesioner ini terdiri dari dua set yaitu (1) kuisioner untuk mengukur variabel kompetensi tenaga kependidikan, dan (2) kuisioner untuk mengukur variable kinerja tenaga kependidikan. Data dalam penelitian ini diperoleh dengan cara memberikan dua set kuisioner kepada tenaga kependidikan yang menjadi responden penelitian ini untuk diisi sesuai dengan pemahaman, pengetahuan, dan pengalaman mereka tentang kompetensi dan kinerja mereka. 2) Dokumentasi adalah merupakan catatan peristiwa yang sudah berlalu. Dokumen bisa berbentuk tulisan, gambar, atau karya-karya monumental dari seseorang. Dokumen yang dikumpulkan terkait pelaksanaan penelitian, variabel kompetensi tenaga kependidikan dan variabel kinerja tenaga kependidikan.

Untuk mengetahui ada atau tidak adanya pengaruh kompetensi terhadap kinerja tenaga kependidikan SMK Negeri 4 Kendari, penulis menggunakan teknik analisis statistik deskriptif dan statistik inferensial kuantitatif dengan menggunakan program SPSS.

\section{HASIL PENELITIAN DAN PEMBAHASAN \\ HASIL PENELITIAN}

Dalam menganalisa pengaruh kompetensi tenaga kependidikan terhadap kinerja tenaga kependidikan, maka peneliti menggunakan statistik inferensial. Akan tetapi, sebelum peneliti menganalisa pengaruh kompetensi tenaga kependidikan terhadap kinerja tenaga kependidikan, peneliti melakukan uji prasyarat terhadap data yang sudah dikumpulkan. Adapun uji prasyarat tersebut adalah uji normalitas dan homogenitas data.

\section{Uji normalitas dan homogenitas data kompetensi tenaga kependidikan dan kinerja tenaga kependidikan}

Untuk manguji normalitas data, pada penelitian ini maka dilakukan teknik uji Kolmogrov-Smirnov. Jika nilai signifikan (sig) $<0,05$ maka dikatakan normal dan nilai signifikan (sig) > 0,05 maka tidak normal. Berdasarkan hasil analisis data yang dilakukan menggunakan bantuan SPSS 16.0 for windows, maka diperoleh data sebagai berikut:

Tabel 1. Distribusi normal variabel kompetensi tenaga kependidikan dan kinerja tenaga kependidikan

One-Sample Kolmogorov-Smirnov Test

\begin{tabular}{|c|c|c|c|}
\hline & & $\begin{array}{c}\text { Kompetensi_Tenaga_Kep } \\
\text { endi }\end{array}$ & $\begin{array}{c}\text { Kinerja_Tenaga_Kepe } \\
\text { ndi }\end{array}$ \\
\hline $\mathrm{N}$ & & 86 & 86 \\
\hline \multirow[t]{2}{*}{ Normal Parameters ${ }^{a}$} & Mean & 79.45 & 81.15 \\
\hline & $\begin{array}{l}\text { Std. } \\
\quad \text { Deviation }\end{array}$ & 3.645 & 3.500 \\
\hline
\end{tabular}


Most Extreme

Absolute

.084

.087

Differences

Kolmogorov-Smirnov Z

a. Test distribution is Normal.

Berdasarkan tabel tabel 1, distribusi normal variabel kompetensi tenaga kependidikan dan kinerja tenaga kependidikan di atas, maka dapat kita lihat bahwa variabel kompetensi tenaga kependidikan berdistribusi normal dengan tingkat signifikan sebebsar 0.001. Demikian juga halnya dengan variabel kinerja tenaga kependidikan mempunyai distribusi data yang normal dengan tingkat signifikan sebesar 0.003 . hal ini berdasarkan pada kriteria pengujian yang mengatakan bahwa Jika nilai signifikan (sig) $<0,05$ maka dikatakan normal dan nilai signifikan (sig) > 0,05 maka tidak normal. Oleh karena masing-masing dari data variabel mempunyai tingkat signifikan yang lebih kecil, maka dapat disimpulkan bahwa kedua data tersebut berdistribusi normal.

Uji prasyarat yang lain yang digunakan sebelum melakukan uji statistika inferensial adalah melihat homogenitas dari kedua data yang dikumpulkan. Untuk mengetahui apakah data yang di peroleh tersebut homogen atau tidak, maka dapat di uji dengan rumus berikut ini:

$$
F_{\text {hitung }}=\frac{\text { Varians Terbesar }}{\text { Varians Terkesil }} \quad \text { Riduwan, 2010:190) }
$$

Berdasarkan hasil tabulasi angket yang dilakukan terhadap variabel kompetensi tenaga kependidikan dan kinerja tenaga kependidikan, maka diperoleh varians dari data kompetensi tenaga kependidikan adalah 13,28 sedangkan varians dari data kinerja tenaga kependidikan adalah 12,24 . Sehingga :

$$
\begin{aligned}
& F_{\text {hitung }}=\frac{1, Z}{1,2} \\
& F_{\text {hitung }}=1,08 .
\end{aligned}
$$

Kriteria pengujian: terima $\mathrm{H}_{0}$ hanya jika $\mathrm{F}_{\text {hit }}<\mathrm{F}_{\text {tabel }}$ yang berarti varians kedua kelompok homogen, dan tolak $\mathrm{H}_{0}$ jika $\mathrm{F}_{\text {hit }} \geq \mathrm{F}_{\text {tabel }}$ yang berarti varians kedua data tidak homogen. Oleh karena $F_{\text {hit(0,05)(85,85) }} 1,08<F_{\text {tabel }}(0,05)(85,85) 1,47$. Dengan demikian kedua data tersebut memiliki varians yang homogen.

\section{Uji korelasi variabel kompetensi tenaga kependidikan dan kinerja tenaga kependidikan}

Untuk mengetahui tingkat pengaruh yang diberikan oleh variabel kompetensi tenaga kependidikan terhadap kinerja tenaga kependidikan, peneliti terlebih dahulu harus mengetahui tingkat hubungan dari kedua variabel tersebut. Berikut hasil uji korelasi yang dilakukan dengan bantuan SPSS 16.0 for windows. Berdasarkan hasil analisis korelasi Pearson di atas dengan menggunakan bantuan SPSS 16.0 for windows, diperoleh data bahwa nilai korelasi antara kompetensi tenaga kependidikan dengan kinerja tenaga kependidikan adalah 0,671. Untuk lebih jelasnya dapat dilihat pada tabel berikut ini: 
Tabel 2. Hasil analisis korelasi pearson menggunakan bantuan SPSS 16.0 for windows

\section{Correlations}

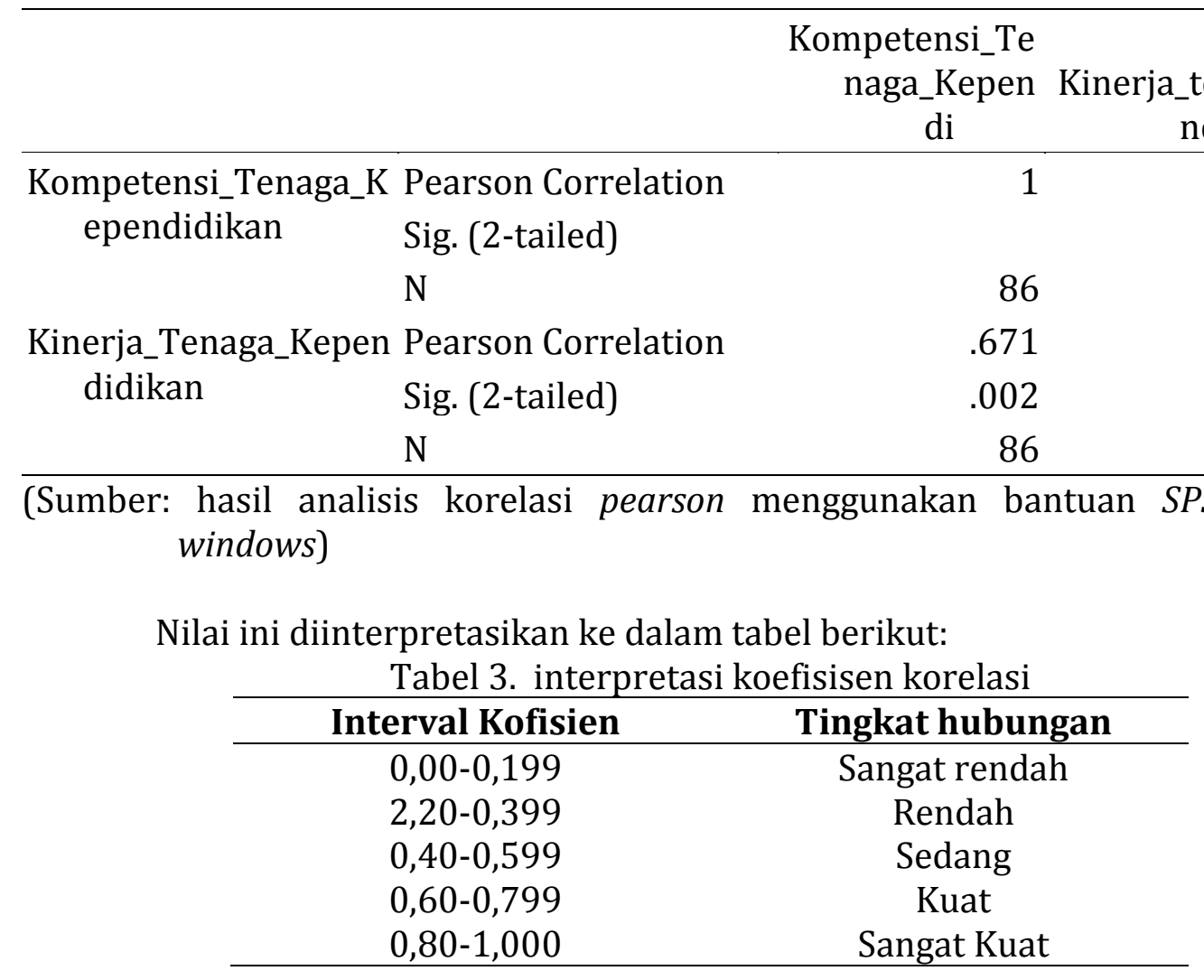

Berdasarkan tabel interpretasi koefisien korelasi di atas, maka dapat diketahui bahwa kompetensi tenaga kependidikan mempunyai hubungan yang berada pada kategori kuat dengan kinerja tenaga kependidikan dengan koefisien korelasi sebesar 0,671 .

\section{Uji Koefisien Determinasi}

Untuk mengetahui seberapa besar variabel X memberikan kontribusi terhadap perubahan variabel Y maka digunakan koefisien determinasi. Koefisien determinasi diperoleh dengan mengkuadratkan koefisien korelasi yang diperoleh (dinyatakan dalam bentuk persen \%):

$$
\begin{aligned}
& D=r^{2} \times 100 \% \\
& D=r_{x y}^{2} \times 100 \% . \\
& D=0,6712 \times 100 \% . \\
& D=45,02 \%
\end{aligned}
$$

Dari hasil analisis tersebut diperoleh bahwa kompetensi tenaga kependidikan mempunyai pengaruh sebesar $45,02 \%$ terhadap kinerja tenaga kependidikan di SMK Negeri 4 Kendari sedangkan sisanya sebesar 54,98\% dipengaruhi oleh faktor lain yang tidak diteliti dalam penelitian ini.

\section{Uji Regresi Linnear Sederhana}

Uji regresi pada penelitian ini adalah regresi linnear sederhan digunakan untuk mengetahui besarnya hubungan dan pengaruh variabel independen (X) terhadap variabel dependen (Y). Dimana jumlah variabel bebas dan variabel terikat tidak lebih dari satu. Dalam melakukan analisis regresi linnear sederhana ini, peneliti 
menggunakan bantuan program SPSS 16.0 for windows. Adapun hasil analisis yang dilakukan dapat dilihat pada tabel berikut ini.

Tabel 4. Anova hasil analisis regresi

\begin{tabular}{llrrrrr}
\multicolumn{7}{c}{ ANOVA $^{\mathbf{b}}$} \\
\multicolumn{1}{l}{ Model } & Sum of Squares & Df & Mean Square & F & \multicolumn{1}{c}{ Sig. } \\
\hline 1 & Regression & 5.680 & 1 & 5.680 & 3.425 & $.002^{\text {a }}$ \\
& Residual & 1123.634 & 84 & 13.377 & & \\
& Total & 1129.314 & 85 & & & \\
\hline
\end{tabular}

a. Predictors: (Constant),

Kinerja_Tenaga_Kependidikan

b. Dependent Variable: Kompetensi_Tenaga_Kependi

Berdasarkan tabel Anova diperoleh nilai F adalah 3.425 dengan tingkat signifikasi $0,002<\alpha(5 \%)$. Dengan demikian persamaan regresi ini dapat digunakan untuk memprediksi perubahan pada kinerja tenaga kependidikan di SMK Negeri 4 Kendari.

Sedangkan perubahan yang kemungkinan terjadi pada kinerja tenaga kependidikan tersebut dapat dilihat pada tabel berikut ini:

Tabel 5. Hasil analisis regresi linnear sederhana

Coefficients $^{\mathrm{a}}$

\begin{tabular}{|c|c|c|c|c|c|c|}
\hline \multirow{2}{*}{\multicolumn{2}{|c|}{ Model }} & \multicolumn{5}{|c|}{$\begin{array}{c}\text { Standardized } \\
\text { Coefficien } \\
\text { ts }\end{array}$} \\
\hline & & $\mathrm{B}$ & Std. Error & Beta & $\mathrm{t}$ & Sig. \\
\hline \multirow[t]{2}{*}{$\overline{1}$} & (Constant) & 85.448 & 9.207 & & 9.280 & .000 \\
\hline & $\begin{array}{c}\text { Kinerja_Tenaga_ } \\
\text { Kependi }\end{array}$ & 4.074 & .113 & .071 & 6.652 & .001 \\
\hline
\end{tabular}

a. Dependent Variable: Kompetensi_Tenaga_Kependidikan

(Sumber: Hasil analisis regresi linnear sederhana menggunakan SPSS 16.0 for windows.)

Berdasarkan hasil analisis regresi yang dilakukan dengan menggunakan bantuan SPSS 16.0 for Windows diperoleh persamaan regresi antara kompetensi tenaga kependidikan dengan kinerja tenaga kependidikan sebagai berikut; $\hat{Y}=$ 85,448+4,074X. Hal ini berarti:

1) Jika kompetensi tenaga kependidikan tidak ditingkatkan dari jumlah indikator yang digunakan pada penelitian ini yaitu 85,448, maka tidak akan terjadi perubahan pada kinerja tenaga kependidikan;

2) Jika kompetensi tenaga kependidikan mengalami peningkatan sebesar satu indikator dari hasil penelitian yang ada, maka akan berpengaruh terhadap kinerja tenaga kependidikan sebesar 4,074 point dari hasil penelitian yang ada. 


\section{Uji t}

Analisis uji t dilakukan peneliti untuk menguji hipotesis penelitian yang mana.

$\mathrm{H}_{0} \quad$ : tidak ada pengaruh positif dan signifikan antara kompetensi tenaga kependidikan terhadap kinerja tenaga kependidikan di SMK Negeri 4 Kendari.

$\mathrm{H}_{1} \quad$ : ada pengaruh positif dan signifikan antara kompetensi tenaga kependidikan terhadap kinerja tenaga kependidikan di SMK Negeri 4 Kendari.

Berdasarkan hasil analisis di uji $t$, diketahui bahwa nilai $t_{\text {hitung }}$ hasil penelitian adalah 8,34 > 2,000 ( $\left.\mathrm{t}_{\text {tabel }}\right)$. Berdasarkan hipotesis pengujian yang mengatakan bahwa:

- Bila thitung $>t_{\text {tabel }}$ maka $\mathrm{H}_{1}$ diterima dan $\mathrm{H}_{\mathrm{o}}$ ditolak

- Bila $t_{\text {hitung }}<\mathrm{t}_{\text {tabel }}$ maka $\mathrm{H}_{1}$ ditolak dan $\mathrm{H}_{\mathrm{o}}$ diterima.

Oleh karena hasil $t_{\text {hitung }}>t_{\text {tabel, }}$ maka $\mathrm{H}_{1}$ diterima. Dengan kata lain bahwa ada pengaruh positif dan signifikan antara kompetensi tenaga kependidikan terhadap kinerja tenaga kependidikan di SMK Negeri 4 Kendari yaitu sebesar 45,02\% sedangkan 54,98\% dipengaruhi oleh faktor lain yang tidak diteliti dalam penelitian ini.

\section{PEMBAHASAN}

Beberapa faktor penentu kinerja tenaga kependidikan adalah adanya kompetensi yang memadai dari tenaga kependidikan itu sendiri. Dengan kata lain, kinerja akan berbanding lurus dengan kompetensi yang dimiliki oleh seorang tenaga kependidikan. Ini berarti bahwa semakin baik kompetensi yang dimiliki oleh seorang tenaga kependidikan maka akan semakin baik pula kinerja yang akan diperolehnya. Sebaliknya, semakin rendah kompetensi seseorang maka akan semakin rendah pencapaian kinerja yang ditunjukkannya. Inilah yang menjadi dasar pikiran dalam melaksanakan penilaian untuk melakukan penelitian ini.

Berdasarkan hasil penelitian yang dilakukan, diperoleh informasi bahwa kompetensi tenaga kependidikan mempunyai pengaruh sebesar 45,02\% terhadap kinerja tenaga kependidikan di SMK Negeri 4 Kendari sedangkan sisanya sebesar $54,98 \%$ dipengaruhi oleh faktor lain yang tidak diteliti dalam penelitian ini. Hal ini menujukkan bahwa kompetensi tenaga kerja merupakan salah satu aspek yang dapat mempengaruhi kinerja tenaga kependidikan. SMK Negeri 4 Kendari menjadi salah satu contoh pembuktian dimana kompetensi tenaga kependidikan memberikan pengaruh sebesar 45,02\% terhadap kinerja tenaga kependidikan di SMK Negeri 4 Kendari sedangkan sisanya sebesar $54,98 \%$ dipengaruhi oleh faktor lain yang tidak diteliti dalam penelitian ini.

Berdasarkan hasil penelitian yang dilakukan, peneliti juga menemukan data yang mampu memprediksi perubahan pada kinerja tenaga kependidikan ketika terjadi perubahan pada kompetensi tenaga kependidikan di SMK Negeri 4 Kendari. Hal ini berdasarkan pada hasil analisis regresi linear sederhana yang dilakukan yang menunjukkan bahwa variabel kompetensi tenaga kependidikan memberikan pengaruh terhadap kinerja tenaga kependidikan dengan persamaan regresi yaitu $\hat{Y}=$ $85,448+4,074 X$. Hal ini berarti: 
a. Jika kompetensi tenaga kependidikan tidak ditingkatkan dari jumlah indikator yang digunakan pada penelitian ini yaitu 85,448, maka tidak akan terjadi perubahan pada kinerja tenaga kependidikan;

b. Jika kompetensi tenaga kependidikan mengalami peningkatan sebesar satu indikator dari hasil penelitian yang ada, maka akan berpengaruh terhadap kinerja tenaga kependidikan sebesar 4,074 point dari hasil penelitian yang ada.

Hal ini menujukkan bahwa kompetensi tenaga kependidikan di SMK Negeri 4 Kendari mempunyai pengaruh yang signifikan terhadap kinerja tenaga kependidikan. Hal ini disebabkan tingkat hubungan yang dimiliki antara variabel kompetensi tenaga kependidikan dengan variabel kinerja tenaga kependidikan berada pada katergori kuat dengan koefisien korelasi sebesar 0,671. Sedangkan untuk mengetahui persentase pengaruh kompetensi tenaga kependidikan terhadap kinerja tenaga kependidikan, maka peneliti menggunakan analisis koefisien determinasi. Dari hasil analisis tersebut diperoleh bahwa kompetensi tenaga kependidikan mempunyai pengaruh sebesar 45,02\% terhadap kinerja tenaga kependidikan di SMK Negeri 4 Kendari sedangkan sisanya sebesar $54,98 \%$ dipengaruhi oleh faktor lain yang tidak diteliti dalam penelitian ini.

Hal ini sejalan dengan pendapat Yudistira dan Siwantara (2017), yang menjelaskan bahwa kompetensi berpengaruh positif dan signifikan secara langsung terhadap kinerja karyawan. Selanjutnya Sriwidodo (2010), mengatakan bahwa kinerja dan keefektifan pegawai dalam melaksanakan tugas sangat ditentukan oleh kompetensi yang disyaratkan oleh bidang pekerjaan. Melalui kompetensi yang semakin memadai seseorangakan lebih menguasai dan mampu menerapkan secara praktek semua tugas pekerjaan sesuai dengan job description yang ditetapkan. Kompetensi pegawai yang semakin tinggi dapat diukur dari semakin bertambahnya pengetahuan dan keterampilan serta semakin berkembangnya perangai atau sifat dan konsep diri yang semakin baik

Selanjutnya untuk membuktikan hipotesis penelitian yang mengatakan bahwa ada pengaruh positif dan signifikan antara kompetensi terhadap kinerja tenaga kependidikan di SMK Negeri 4 Kendari peneliti menggunakan analisis uji t. Berdasarkan hasil analisis di atas, diketahui bahwa nilai thitung hasil penelitian adalah 8,34 > 2,000 ( $\mathrm{t}_{\text {tabel }}$ ) oleh karena hasil $t_{\text {hitung }}>\mathrm{t}_{\text {tabel, }}$ maka $\mathrm{H}_{1}$ diterima. Dengan kata lain bahwa ada pengaruh positif dan signifikan antara kompetensi tenaga kependidikan terhadap kinerja tenaga kependidikan di SMK Negeri 4 Kendari yaitu sebesar 45,02\% sedangkan 54,98\% dipengaruhi oleh faktor lain yang tidak diteliti dalam penelitian ini.

Berdasarkan hasil penelitian dan pembahasan di atas, maka dapat disimpulkan bahwa (1) kompetensi tenaga kependidikan di SMK Negeri 4 Kendari berada pada kategori baik dengan nilai persentase sebesar 79,45\%. (2) kinerja tenaga kependidikan di SMK Negeri 4 Kendari berada pada kategori baik dengan nilai persentase yang diperoleh sebesar 81,51\%. (3) Ada pengaruh positif dan signifikan antara kompetensi tenaga kependidikan terhadap kinerja tenaga kependidikan di SMK Negeri 4 Kendari yaitu sebesar 45,02\% dengan nilai koefisien korelasi sebesar 0,671 dan persamaan regresi linear sederhana dengan nilai $\hat{Y}=85,448+4,074 \mathrm{X}$ sedangkan selebihnya yaitu $54,98 \%$ dipengaruhi oleh faktor lain yang tidak diteliti dalam penelitian ini. 
Berdasarkan hasil penelitian tersebut, maka ditemukan bahwa ada perbedaan antara hasil penelitian yang dilakukan peneliti dengan penelitian relevan yakni: 1) jenis penelitian yang digunakan adalah jenis penelitian kuantitatif, 2) variabel yang digunakan terdiri variabel kompetensi dan kinerja tenaga kependidikan. 3) hasil penelitian yang menunjukan bahwa ada pengaruh positif dan signifikan antara kompetensi tenaga kependidikan terhadap kinerja tenaga kependidikan di SMK Negeri 4 Kendari yaitu sebesar 45,02\%.

\section{SIMPULAN}

Berdasarkan hasil penelitian dan pembahasan yang dilakukan pada BAB sebelumnya, maka peneliti menyimpulkan bahwa: ada pengaruh positif dan signifikan antara kompetensi tenaga kependidikan terhadap kinerja tenaga kependidikan di SMK Negeri 4 Kendari yaitu sebesar 45,02\% dengan nilai koefisien korelasi sebesar 0,671 dan persamaan regresi linear sederhana dengan nilai $\hat{Y}=$ $85,448+4,074 \mathrm{X}$ sedangkan selebihnya yaitu $54,98 \%$ dipengaruhi oleh faktor lain yang tidak diteliti dalam penelitian ini.

\section{UCAPAN TERIMA KASIH}

Penulis menyampaikan ucapan terima kasih dan penghargaan kepada Bapak Muh. Alamsah, S.Pd., M.Hum. selaku pembimbing I dan Ibu Apriani Safitri, S.Pd., M.Pd selaku pembimbing II yang telah sabar, tekun, tulus dan ikhlas meluangkan waktu, tenaga dan pikiran memberikan bimbingan, motivasi, arahan, dan saran-saran yang sangat berharga kepada penulis selama menyusun hasil ini, dan seluruh civitas akademika Program Studi Administrasi Pendidikan, Fakultas Keguruan dan Ilmu Pendidikan, Universitas Muhammadiyah Kendari.

\section{DAFTAR PUSTAKA}

Abdullah, M. 2014. Manajemen dan Evaluasi Kinerja Karyawan. Yogyakarta : Penerbit Aswaja Pressindo.

Arikunto. 2006. Prosedur Penelitian Satuan Pendekatan Praktek, Jakrta: Rineka Cipta

Amin Widjaja Tunggal. 2013. The Fraud Audit: Mencegah dan Mendeteksi Kecurangan Akuntansi. Jakarta: Harvarindo

Ardi Ramadhan Nur dan Dedik Wiryawan. 2019. Pengaruh Motivasi Kerja Dan Kompetensi Terhadap Kinerja Tenaga Pendidik Dan Tenaga Kependidikan Universitas

Kaltara. https://www.researchgate.net/publication/335542063 pengaruh motivasi $\mathrm{k}$ erja dan kompetensi terhadap kinerja tenaga pendidik dan tenaga kependid ikan universitas kaltara diakses pada tanggal 13 April 2020.

Mulyadi. 2013. Sistem Akuntansi. Jakarta: Salemba Empat

Moeheriono. 2012. Pengukuran Kinerja Berbasis Kompetensi. Jakarta: Raja Grafindo Persada.

Permendiknas No. 24 Tahun 2008 tentang Standar Tenaga Administrasi Sekolah/Madrasah

Riduwan, 2010, Belajar mudah Penelitian Untuk Guru-Karyawan dan Peneliti Pemula, Bandung: Alfabeta 2010.Rumus Dan Data Dalam Aplikasi Statistik, bandung: alfabeta

Rusman. 2011. Model-Model Pembelajaran Mengembangkan Profesionalisme Guru. Jakarta: PT. Rajagrafindo Persada. 
Sugiyono. 2015. Metode Penelitian Pendidikan. Bandung: Alfabeta

Sriwidodo, Untung dan Agus Budhi Haryanto. (2010). Pengaruh Kompetensi, Motivasi, Komunikasi Dan Kesejahteraan Terhadap Kinerja Pegawai Dinas Pendidikan. Jurnal Manajemen Sumber Daya Manusia, 4(1): h:47-57.

Undang-Undang Sistem Pendidikan Nasional No. 20 Tahun 2003

Wibowo, 2010, Manajemen Kinerja, Jakarta: Rajawali Pers

Wulan Sari. 2014. Skripsi: Pembinaan Profesionalitas Tenaga Administrasi Sekolah/Madrasah Di SD/MI Se-Kecamatan Pleret Kabupaten Bantul. Program Studi Manajemen Pendidikan Jurusan Administrasi Pendidikan Fakultas Ilmu Pendidikan Universitas Negeri Yogyakarta

Wenny Fitria Azizah. 2016. Skripsi: Analisis Kompetensi Tenaga Tata Usaha Untuk Meningkatkan Kualitas Administrasi Sekolah Di SMP Negeri 4 Yogyakarta, Jurusan Kependidikan Islam Fakultas Ilmu Tarbiyah Dan Keguruan Universitas Islam Negeri Kalijaga Yogyakarta

Yahya, Muhammad. 2018. Tantangan dan Peluang Perkembangan Pendidikan Kejuruan Indonesia. Disampaikan pada sidang terbuka luar biasa senat Universitas Negeri Makasar tanggal 14 Maret 2018, Makasar. 